\title{
Behavior of Tin and Antimony in Secondary Copper Smelting Process
}

\author{
Lassi Klemettinen ${ }^{1, *} \oplus$, Katri Avarmaa ${ }^{1}$, Hugh $\mathrm{O}^{\prime}$ Brien $^{2}$, Pekka Taskinen ${ }^{1}$ \\ and Ari Jokilaakso ${ }^{1}$ (D) \\ 1 Department of Chemical and Metallurgical Engineering, Aalto University, Kemistintie 1, P.O. Box 16100, \\ FI-00076 Aalto, Finland; katri.avarmaa@aalto.fi (K.A.); pekka.taskinen@aalto.fi (P.T.); \\ ari.jokilaakso@aalto.fi (A.J.) \\ 2 Geological Survey of Finland (GTK), Betonimiehenkuja 4, 02150 Espoo, Finland; hugh.obrien@gtk.fi \\ * Correspondence: lassi.klemettinen@aalto.fi; Tel.: +358-44-214-9569
}

Received: 18 December 2018; Accepted: 8 January 2019; Published: 12 January 2019

\begin{abstract}
Different types of metal-bearing wastes, such as WEEE (Waste Electrical and Electronic Equipment), are important urban minerals in modern society, and the efficient recycling and reuse of their metal values is of key interest. Pyrometallurgical copper smelting is one of the most prominent ways of treating WEEE, however, more accurate experimental data is needed regarding the behavior of different elements during each process stage. This article investigates the behavior of tin and antimony, both commonly present as trace elements in electrical and electronic waste, in secondary (i.e., sulfur-free) copper smelting conditions. The experiments were conducted in oxygen partial pressure range of $10^{-10}-10^{-5} \mathrm{~atm}$, covering the different process steps in copper smelting. The basis of the equilibrium system was metallic copper-iron silicate slag, with the addition of alumina and potassium oxide to account for the presence of these compounds in the actual industrial process. The results showed that the distribution coefficients of both trace metals, $\mathrm{L}^{\mathrm{Cu} / \mathrm{slag}}=[\mathrm{wt} \% \mathrm{Me}]_{\text {copper }} /(\mathrm{wt} \% \mathrm{Me})_{\text {slag, }}$, increased significantly as a function of decreasing oxygen pressure, and the addition of basic potassium oxide also had an increasing effect on the distribution coefficient. A brief comparison between EPMA and LA-ICP-MS (electron probe microanalysis and laser ablation-inductively coupled plasma-mass spectrometry), the two in situ analytical techniques used, was also presented and discussed.
\end{abstract}

Keywords: distribution; slag; urban mining; circular economy; copper smelting

\section{Introduction}

Pyrometallurgical copper smelting is one of the most efficient and widely used ways of treating Waste Electrical and Electronic Equipment (WEEE) and recovering the valuable metals within. This processing method can be further divided into several routes: in primary copper smelters, WEEE is typically added to Peirce-Smith or Kaldo/TSL-type converters. One disadvantage of most primary smelters, regarding the handling of significant quantities of WEEE, is the remote location of the plants, as this scrap is mostly produced in urban areas and long-distance transportation is neither economically nor environmentally favorable. Thus, secondary copper smelters are more attractive, since they can be reasonably located closer to the WEEE collection network and operate economically with a smaller throughput compared to primary smelters [1]. The proximity to urban areas means that special attention must be paid to the handling of toxic emissions, such as dioxins and furans, potentially generated by WEEE-based secondary copper smelting [2,3]. However, with proper design and control of the entire smelting operation and especially the off-gas train, these emissions can be efficiently eliminated [3,4]. 
Secondary smelters can either produce a copper matte (for example Umicore [1,5]), or black copper from metallic and oxidic raw materials, such as electronic scrap [6-8]. The present study focuses on the different stages of the latter process and illustrates experimental observations on how tin and antimony as trace elements behave in black copper smelting conditions with alumina and potassium oxide containing slags. These oxides may not necessarily play a significant role in primary copper smelting, but can be present in considerable amounts when processing secondary raw materials, such as electronic waste.

When considering electronic appliances, tin is commonly used as a solder material, as well as in indium tin oxide (ITO) layers found for example in transparent, conductive display coatings. The concentration of tin in EEE varies from approximately 1 to $4 \mathrm{wt} \%$ [9]. Due to the comparatively high concentration of tin in electronic scrap, and consequently its notable effect on the recycling systems, the behavior of tin has been studied in different processes. Examples include different pretreatment methods [10], leaching [11-13] and pyrometallurgical waste processing. Focusing on the latter, studies have been conducted in tin-slag systems providing maximum solubility of tin in different types of slags [14-18] and, for relevant comparisons with the results of this study, in different copper-slag systems [19-27]. However, no data exists on the effect of alkali metal oxides in slag, in this case $\mathrm{K}_{2} \mathrm{O}$, on the distribution behavior of tin with high-alumina slags common in secondary copper smelting processes.

Antimony is a common impurity in chalcopyrite, which is the most important sulfide mineral in primary copper production [28]. Antimony is used in a range of applications, such as rechargeable batteries, semiconductors and as a synergist for brominated flame retardants used in plastics. These antimony-containing plastics are also commonly used in manufacturing of electronic appliances $[28,29]$ As antimony is from the same group as arsenic in the periodic table and shares similar biological and chemical properties, some regulations regarding for example the concentration of antimony in landfilled materials have already been implemented [30,31]. In the future, we may see regulatory limits for the concentration of antimony in electronic appliances as well [29]. It is worth recovering from different types of wastes as it has been classified as a toxic substance [30] and its mine reserves are decreasing rapidly [32]. Antimony was also classified as a critical raw material, with the largest expected deficit of all critical metals between 2015-2020, according to the European Commission [33].

Some studies have been conducted regarding the recovery of antimony from WEEE, MSWI (Municipal Solid Waste Incinerator) bottom ash and flue dusts by leaching $[29,31,34,35]$ and from the plastic fraction of WEEE by staged-gasification [36,37]. The distribution of antimony between copper and different slags has also been studied by some authors previously [21,38-43]. Similarly as for tin, no studies regarding the effect of alkali metal oxides on the distribution behavior of antimony were found.

In this study, the distribution of tin and antimony between metallic copper and iron-alumina spinel saturated iron silicate slag, with $0-5 \mathrm{wt} \% \mathrm{~K}_{2} \mathrm{O}$, was experimentally studied. The experimental temperature was selected as $1300{ }^{\circ} \mathrm{C}$, which is in the same range as processing temperatures in industrial operations. The oxygen partial pressure range of interest was from $10^{-10}$ to $10^{-5}$ atm $\left(10^{-5}-1 \mathrm{~Pa}\right)$, covering most of the process steps in copper smelting. Industrial oxygen pressures are in the order of $10^{-8} \mathrm{~atm}$ in typical copper matte smelting, $10^{-11} \mathrm{~atm}$ in reducing matte smelting in a blast furnace or slag cleaning furnace, $10^{-6}-10^{-5} \mathrm{~atm}$ in converter, and $10^{-5}-10^{-4} \mathrm{~atm}$ in anode furnace. In different stages of sulfur-free black copper smelting, the partial pressure of oxygen is typically between $10^{-9}$ and $10^{-6} \mathrm{~atm}[44]$.

\section{Materials and Methods}

A vertical tube furnace (RHTV 120-150/18, Nabertherm, Lilienthal, Germany) equipped with $\mathrm{MoSi}_{2}$ heating elements, Nabertherm P310 temperature controller and an alumina work tube (impervious pure alumina, $45 / 38 \mathrm{~mm}$ OD/ID), was used for the laboratory scale copper alloy-slag-gas equilibration experiments. Temperature measurement was performed with a calibrated $\mathrm{Pt} / \mathrm{Pt} 10 \mathrm{Rh}$ 
thermocouple (Johnson-Matthey, London, UK, accuracy $\pm 3{ }^{\circ} \mathrm{C}$; calibrated by the manufacturer according to ITS-90 standard, using the melting temperatures of palladium in air and gold as reference points), which was located next to the sample and connected to a Keithley 2010 DMM multimeter (Keithley, Solon, OH, USA; calibrated by the manufacturer). Cold junction compensation was performed by a Pt100 resistance thermometer (SKS-Group, Vantaa, Finland, accuracy class 1/10 B; calibrated in $0{ }^{\circ} \mathrm{C}$ ice-water mixture), connected to a Keithley $2000 \mathrm{DMM}$ multimeter (Keithley, Solon, $\mathrm{OH}, \mathrm{USA}$; calibrated by the manufacturer). The desired oxygen partial pressures inside the furnace work tube were obtained with $\mathrm{CO}-\mathrm{CO}_{2}$ gas mixture, with a total flow rate of $300 \mathrm{~mL} / \mathrm{min}$ (NTP). A schematic of the furnace set-up is presented in Figure 1, and the full list of experiments as well as corresponding gas flows have been collected in Appendix A, Table A1.

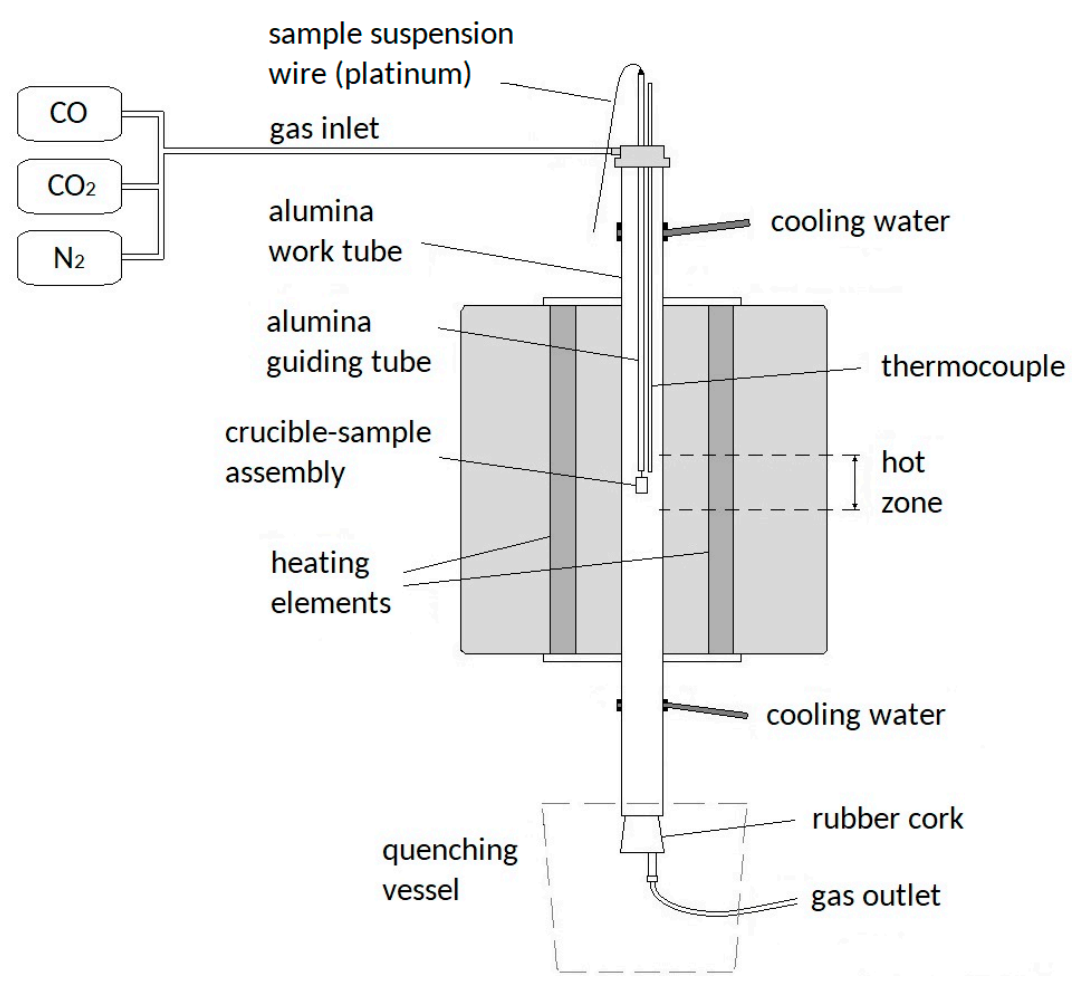

Figure 1. A schematic of the experimental furnace set-up.

The copper alloy and slag mixtures were prepared from pure powders. The copper alloy was mixed of copper (99.999\%, Alfa Aesar, Kandel, Germany) with 1 wt \% of Ni (99.996\%, Alfa Aesar), Sn (99.85\%, Alfa Aesar), Sb (99.9\%, Alfa Aesar), and Te (99.99\%, Alfa Aesar). The slag, with an initial $\mathrm{Fe} / \mathrm{SiO}_{2}$ ratio of 1.3, was mixed of $\mathrm{SiO}_{2}\left(99.99 \%\right.$, Umicore, Balzers, Liechtenstein) and $\mathrm{Fe}_{2} \mathrm{O}_{3}$ (99.99\%, Alfa Aesar). Approximately 3 and $5 \mathrm{wt} \%$ of $\mathrm{K}_{2} \mathrm{O}$ (initially as $\mathrm{K}_{2} \mathrm{CO}_{3}, 99.5 \%$, Sigma-Aldrich, St. Louis, MO, USA) were added to the second and third slag mixture, respectively, for investigating the effect of potassium oxide on the equilibrium system. The $\mathrm{K}_{2} \mathrm{CO}_{3}$ addition was kept constant throughout the oxygen partial pressure range. $200 \mathrm{mg}$ of both copper alloy and slag mixtures were weighed into small alumina crucibles (Frialit AL23, Friatec, Mannheim, Germany, 8/15 mm ID/H, respectively), which were suspended in the furnace hot zone by a platinum wire and a platinum basket. The powder mixtures melted and reacted with the crucible, resulting in iron-alumina spinel saturation. After equilibration, the samples were rapidly quenched into ice-water mixture by pulling the platinum wire from the top of the furnace. The quenching vessel (Figure 1) was placed so that no air entered into the furnace work tube during the few seconds between removing the rubber cork and quenching the sample. The sufficiency of the selected 16-h equilibration time was confirmed with time series experiments of 8,16 and $24 \mathrm{~h}$ at $10^{-6} \mathrm{~atm}$ oxygen partial pressure. Duplicate experiments were conducted for 0 and $3 \mathrm{wt} \% \mathrm{~K}_{2} \mathrm{O}$-containing slags in the $\mathrm{pO}_{2}$ range of $10^{-9}-10^{-6}$ atm for reliability, 
and these results have been included in the calculation of average values and standard deviations in the result Figures and Tables A2-A4. This article focuses only on the behavior of tin and antimony. Observations regarding the behavior of nickel have been presented before [45].

After equilibration and quenching, the samples were cut in half and mounted in epoxy resin. Grinding and polishing were performed using traditional dry polishing techniques. SEM-EDS (LEO 1450 scanning electron microscope, Carl Zeiss AG, Oberkochen, Germany, and X-Max $50 \mathrm{~mm}^{2}$ energy dispersive spectrometer, Oxford Instruments, Oxford, UK) was used for determining phase homogeneity and obtaining micrographs. After SEM-EDS, the accurate phase compositions were analyzed directly, phase-by-phase (copper alloy, liquid slag, solid spinel), with EPMA (SX-100 electron microprobe equipped with five wavelength dispersive spectrometers, Cameca SAS, Gennevilliers, France). Eight analysis points were randomly selected from each phase for statistical reliability, and PAP-ZAF matrix correction procedure [46] was employed for raw data processing. An accelerating voltage of $20 \mathrm{kV}$, a beam current of $60 \mathrm{nA}$, and a defocused electron beam (100 $\mu \mathrm{m}$ for copper alloy, 50-100 $\mu \mathrm{m}$ for liquid slag, and $1 \mu \mathrm{m}$ for solid spinel) were employed. The standards utilized in EPMA analyses were hematite $(\mathrm{O} K \alpha$ and $\mathrm{Fe} K \alpha)$, quartz $(\mathrm{Si} K \alpha)$, sanidine $(\mathrm{K} K \alpha)$, tin $(\mathrm{Sn} \operatorname{L} \alpha)$, antimony telluride ( $\mathrm{Sb} \mathrm{L} \alpha$ for copper and spinel, $\mathrm{Sb} \mathrm{L} \beta$ for slag), alumina (Al K $\alpha$ for spinel, Al K $\beta$ for copper and slag), and copper $(\mathrm{Cu} \mathrm{K} \alpha)$. The average concentrations of $\mathrm{Cu}, \mathrm{Sn}$ and $\mathrm{Sb}$ in copper alloy phase have been collected in Table A2. The average concentrations of $\mathrm{Fe}, \mathrm{Si}, \mathrm{Cu}, \mathrm{Al}, \mathrm{K}, \mathrm{Sn}$ and $\mathrm{Sb}$ in slag and spinel phases have been presented in Tables A3 and A4, respectively.

The detection limits of EPMA (Table 1) were low enough to measure the concentration of tin in copper alloy in all experimental conditions, and in slag in the oxidative side of the oxygen partial pressure range investigated. However, in reducing conditions, the measured concentration values in the slags were very close or even below the detection limits. For antimony, the concentrations in slags below $10^{-6}$ atm $\mathrm{pO}_{2}$ were close, or, in the most reducing conditions, significantly below the detection limits. Therefore, LA-ICP-MS (laser ablation-inductively coupled plasma-mass spectrometry) technique was also employed for trace element analysis from the slag phase. A Photon Machines Analyte Excite 193 nm ArF laser ablation machine (Teledyne CETAC Technologies, Omaha, NE, USA) coupled with an ICP-MS device Nu AttoM SC-ICP-MS (Nu Instruments Ltd., Wrexham, UK) was used. The laser spot size was selected as $85 \mu \mathrm{m}$, and the energy was set to $30 \%$ of $5.0 \mathrm{~mJ}$, resulting in a fluence of $2.5 \mathrm{~J} / \mathrm{cm}^{2}$ on the sample surface. The pulse frequency was $10 \mathrm{~Hz}$ with 4 ns laser pulses. The mass spectrometer was operated in FastScan mode in low resolution $(\Delta M / M=300)$ for higher sensitivity. An analysis procedure of 5 preablation pulses, 15-s pause, 15-s gas background analysis, and 400 ablation pulses was adopted.

Table 1. EPMA and LA-ICP-MS elemental/isotopic detection limits for each phase analyzed. ppmw = parts per million by weight.

\begin{tabular}{|c|c|c|c|c|c|c|c|c|}
\hline Phase & $\mathbf{O}$ & Si & Al & $\mathbf{K}$ & $\mathrm{Cu}$ & Sn & $\mathrm{Sb}$ & $\mathrm{Fe}$ \\
\hline \multicolumn{9}{|c|}{ Detection limit (ppmw) EPMA } \\
\hline Copper & 1215 & 273 & 4497 & 116 & 348 & 150 & 169 & 179 \\
\hline Slag & 1443 & 202 & 3258 & 94 & 278 & 124 & 121 & 197 \\
\hline Spinel & 1365 & 193 & 183 & 92 & 272 & 121 & 115 & 195 \\
\hline \multicolumn{9}{|c|}{ Detection limit (ppmw) LA-ICP-MS } \\
\hline Slag & & $\begin{array}{c}12 \\
\left({ }^{29} \mathrm{Si}\right)\end{array}$ & & & & $\begin{array}{c}0.03 \\
\left({ }^{117} \mathrm{Sn}\right) \\
0.02 \\
\left({ }^{118,120} \mathrm{Sn}\right)\end{array}$ & $\begin{array}{c}0.02 \\
\left({ }^{121,123} \mathrm{Sb}\right)\end{array}$ & \\
\hline
\end{tabular}

NIST 612 SRM (standard reference material) [47] was used as the external standard and Si concentration from EPMA (measured with ${ }^{29} \mathrm{Si}$ in LA-ICP-MS) as the internal standard during the analyses. NIST 610 SRM, USGS BHVO-2G and BCR-2G reference materials were analyzed 
as unknowns for monitoring analysis accuracy. The obtained data from the mass spectrometer was analyzed with GLITTER software (ARC National Key Centre for Geochemical Evolution and Metallogeny of Continents (GEMOC) and CSIRO Exploration and Mining, Australia; version 4.4.4) [48]. The LA-ICP-MS detection limits for tin and antimony isotopes used for calculations $\left({ }^{117,118,120} \mathrm{Sn}\right.$, $121,123 \mathrm{Sb}$ ) have been collected in Table 1.

\section{Results}

The equilibrated-quenched samples consisted of three phases; liquid slag, solid iron-alumina spinel and liquid copper alloy. A backscattered electron (BSE) micrograph of sample $\mathrm{V} 15\left(\mathrm{pO}_{2} 10^{-8} \mathrm{~atm}\right)$ is shown in Figure 2. In this oxygen partial pressure, the spinel phase was formed only as a uniform layer at the crucible-slag interface, trapping also some smaller copper alloy droplets. The shape of these droplets seemed to adapt locally to the shape of the surrounding solid spinel phase, more clearly illustrated in Figure 3. DeWilde et al. [49,50] have closely investigated this phenomenon of copper droplets sticking to different types of spinels, and they concluded that this complex phenomenon is influenced by the slag-alloy-spinel composition and the oxygen potential. According to their findings, copper alloy droplets only attach to iron-rich spinels (and not aluminum-rich ones). In our study, the spinel phase contained more iron than aluminum in every oxygen pressure, and the fraction of iron increased as the oxygen pressure increased [45]. Correspondingly, according to SEM micrographs (comparison between Figures 2 and 3), the number of entrained copper droplets also seemed to increase, supporting the findings of DeWilde et al. At higher oxygen pressures, some larger spinel grains became loose from the edge spinel structure and floated within the liquid slag, as shown in Figure 3. These spinel grains also trapped small and medium-size copper alloy droplets, hindering their sedimentation and coalescence. The composition and formation of the spinel phase as a function of time has been discussed previously [45]. Rämä et al. [51] also observed similar copper alloy-spinel interactions in experiments related to pyrometallurgical treatment of jarosite residue.

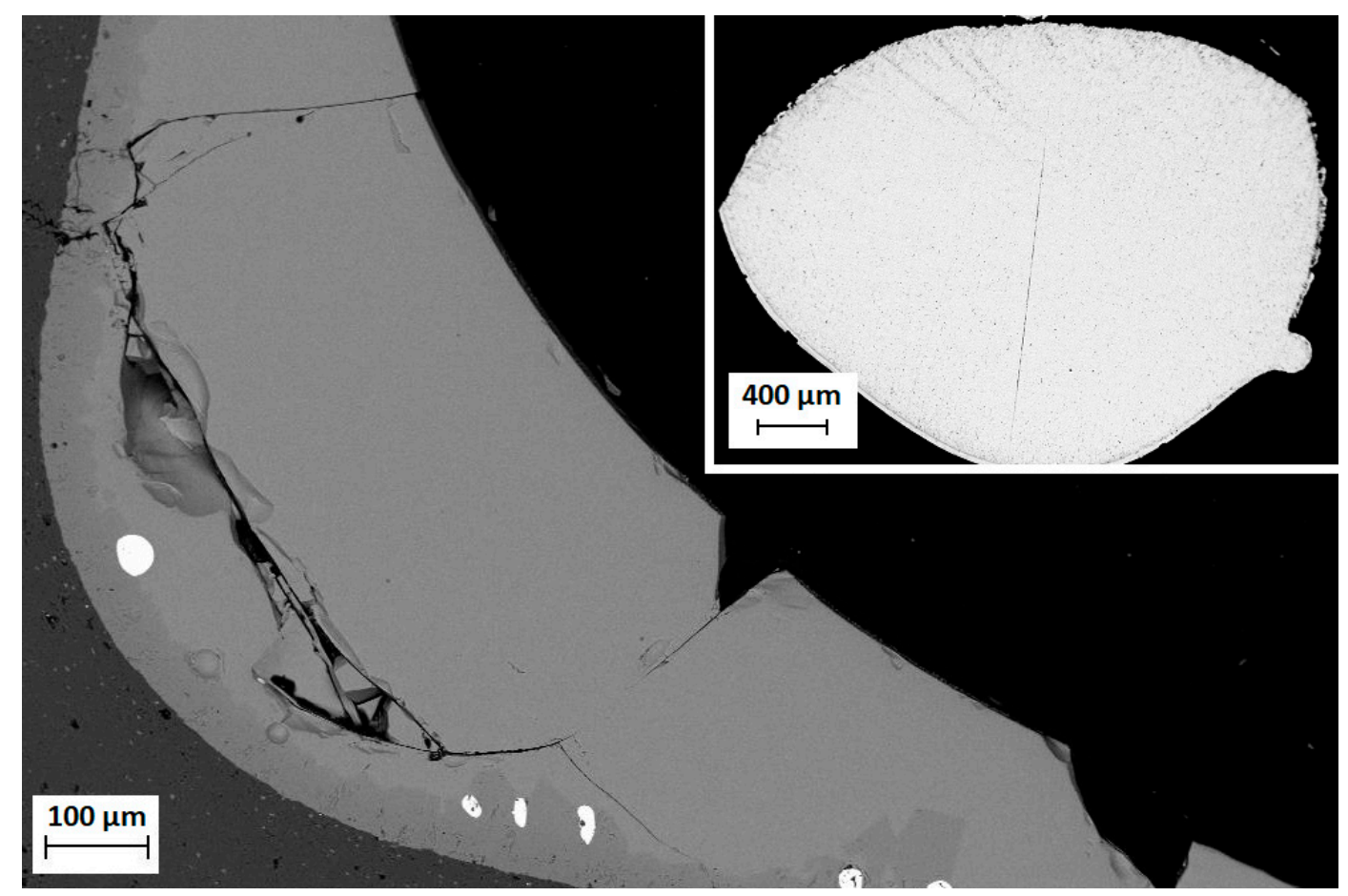

Figure 2. SEM-BSE micrograph of the liquid slag and solid spinel layer in sample V15 $\left(\mathrm{pO}_{2} 10^{-8}\right.$ atm, no $\mathrm{K}_{2} \mathrm{O}$ ). Large copper alloy droplet (detached from the slag during quenching) is shown in the upper right corner. The dark grey in the bottom left corner is the alumina crucible, the medium grey phase is the edge spinel layer, and the lighter grey is liquid slag phase. 

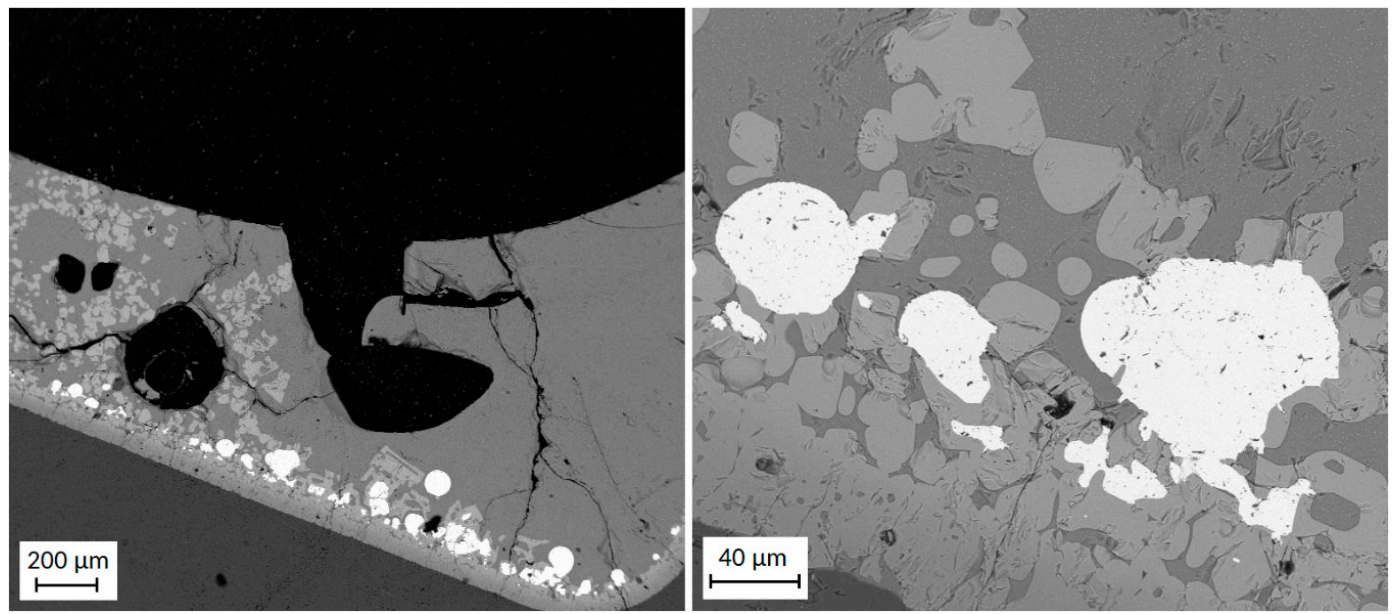

Figure 3. Left side: SEM-BSE micrograph of sample V38 $\left(\mathrm{pO}_{2} 10^{-6} \mathrm{~atm}, 5 \mathrm{wt} \% \mathrm{~K}_{2} \mathrm{O}\right)$. Numerous loose spinel grains were observed floating in the liquid slag and the number of sticking copper alloy droplets was much higher compared to Figure 2. Right side: a close-up of the entrained copper droplets in the same sample; the shape of the liquid droplets has adapted to the surrounding solid spinel structure.

In this study, all the alumina dissolved in the slag and spinel originated from the alumina crucible. The final alumina concentration in the slag phase remained relatively constant at $17-19 \mathrm{wt} \%$ [45], regardless of the potassium oxide concentration shown in Figure 4 right side, and the oxygen partial pressure. However, the $\mathrm{Fe} / \mathrm{SiO}_{2}$-ratio changed dramatically as a function of oxygen partial pressure and $\mathrm{K}_{2} \mathrm{O}$ concentration, as depicted in Figure 4 left side. The initial ratio was 1.3, but this was reduced even down to 0.4 in the most oxidizing conditions, with $5 \mathrm{wt} \% \mathrm{~K}_{2} \mathrm{O}$ containing slag. The decrease can be attributed to the formation of the spinel phase, which consumed part of the iron. As the iron enrichment in the spinel increased with increasing oxygen partial pressure, the $\mathrm{Fe} / \mathrm{SiO}_{2}$ ratio of the slag decreased correspondingly. In addition, the liquid domain and slag boundaries changed significantly as copper solubility in the slags increased in more oxidizing conditions [25]. The difference between the different slags was due to the change in the activity coefficient of iron, caused by the addition of basic potassium oxide.
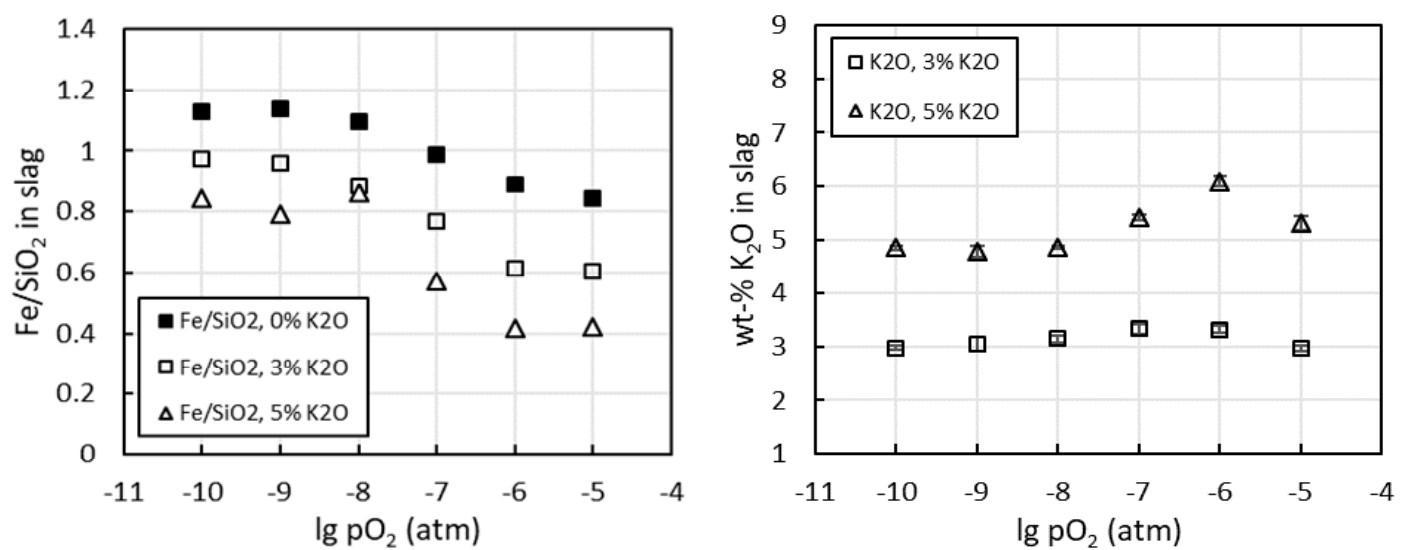

Figure 4. Left side: $\mathrm{Fe} / \mathrm{SiO}_{2}$ ratio in slags after equilibration. Right side: $\mathrm{K}_{2} \mathrm{O}$ concentration in slags as a function of oxygen partial pressure.

The concentrations of tin and antimony in copper alloy phase are presented in Figure 5. In the most reducing conditions, at $\mathrm{pO}_{2} 10^{-10}-10^{-9}$ atm, the concentration of tin in copper alloy was close to the initial concentration, i.e., tin was strongly distributed into the copper alloy. As the conditions became more oxidizing, tin started to oxidize and deport into the slag phase as well. Antimony behaved 
differently, as its concentration in copper alloy remained virtually unchanged between $10^{-10}-10^{-6} \mathrm{~atm}$ oxygen partial pressure. Only in the most oxidizing conditions of this study, its concentration began to decrease. Contrary to an earlier study using silica crucibles [26], the vaporization of tin was not very significant. Notable vaporization was observed only in the most oxidizing conditions of this study, corresponding to the converting stage of secondary copper smelting. The addition of potassium oxide into the slag did not have a systematic effect on the concentration of either trace metal in copper alloy post quenching.
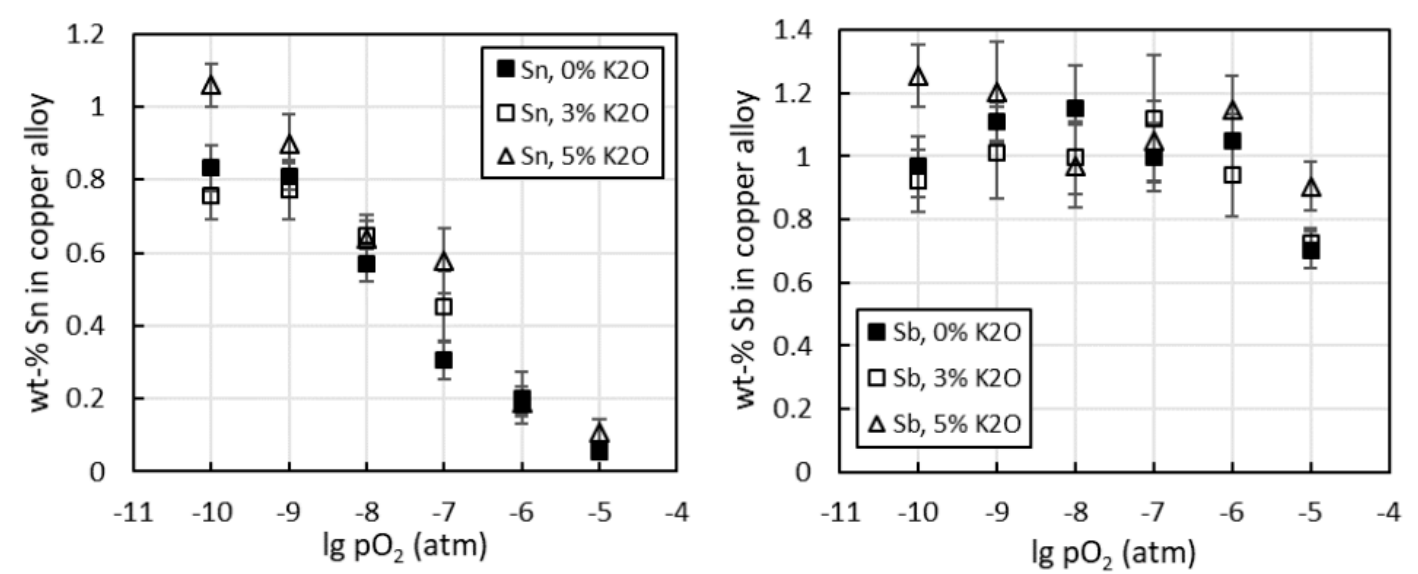

Figure 5. Left side: concentration of tin in copper alloy phase. Right side: concentration of antimony in copper alloy as a function of oxygen partial pressure.

Figure 6 illustrates the concentration of the two trace elements in slag as a function of oxygen partial pressure. LA-ICP-MS results were used below $10^{-8} \mathrm{~atm}$ for tin and below $10^{-6} \mathrm{~atm}$ for antimony. As the oxygen pressure increased, the concentrations of both tin and antimony in the slag increased as well. Potassium oxide addition seemed to decrease the concentration of tin in the slag slightly, similarly as for nickel in the same system [45]. For antimony, this effect was not as clear.
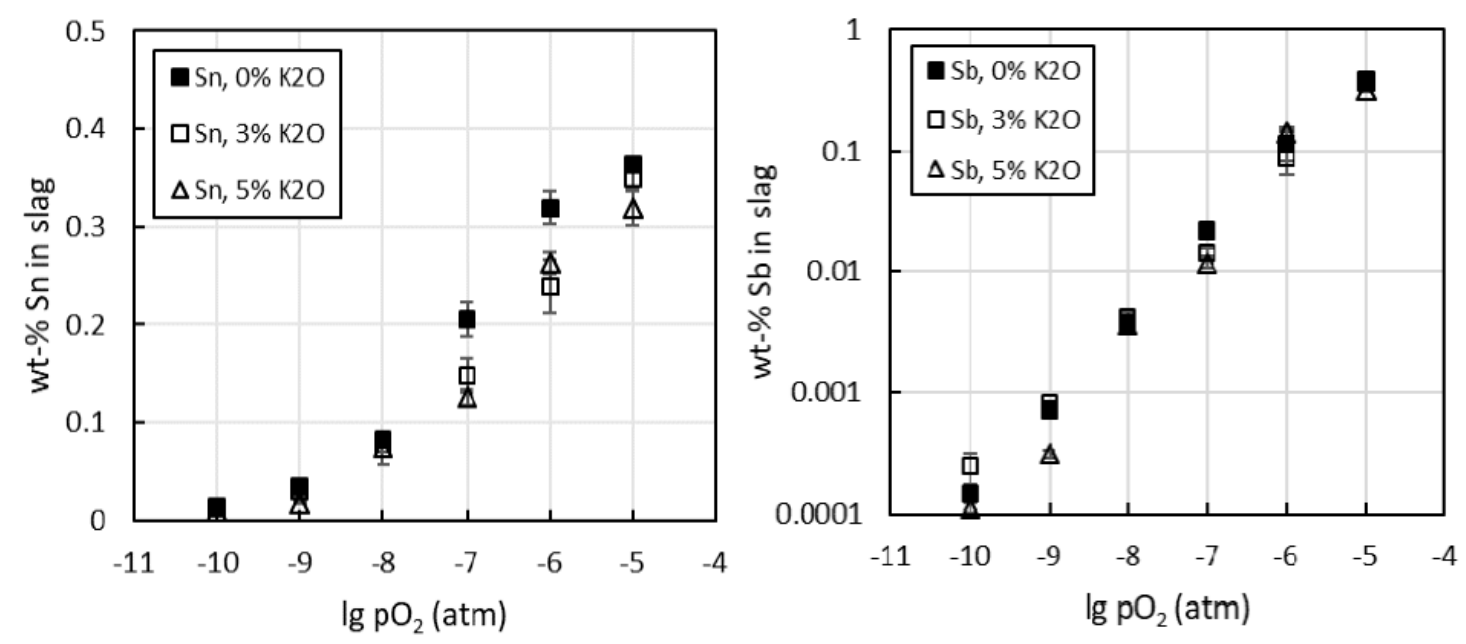

Figure 6. Left side: concentration of tin in liquid slag phase. Right side: concentration of antimony in slags as a function of oxygen partial pressure. For tin, LA-ICP-MS results were used for oxygen partial pressures below $10^{-8} \mathrm{~atm}$, and for antimony below $10^{-6} \mathrm{~atm}$. The concentration of antimony is plotted in logarithmic scale in order show more accurately the low concentrations in reducing conditions.

The concentrations of tin and antimony in the iron-alumina spinel phase were not analyzed with LA-ICP-MS due to the small size of the spinel areas. According to EPMA data, approximately 200 ppmw (no $\left.\mathrm{K}_{2} \mathrm{O}\right)-1200 \mathrm{ppmw}\left(5 \mathrm{wt} \% \mathrm{~K}_{2} \mathrm{O}\right)$ tin deported into the spinel in the most oxidizing 
conditions, and the amount decreased with decreasing oxygen pressure. This is in fair agreement with the solubility values obtained by Avarmaa et al. [25]. For antimony, the concentrations were even lower, close or below the detection limits of EPMA. Considering the concentrations of both elements in copper and slag phases, their losses into the spinel phase were minor.

The effect of potassium oxide on the solubility of copper into the slags is not graphically shown in this article, but the numerical values have been collected in Table A3. Potassium oxide had a clear effect on the copper losses into the slag, most notably in the highest oxygen partial pressure investigated, as the copper concentration decreased from approximately $21 \mathrm{wt} \%$ in $\mathrm{K}_{2} \mathrm{O}$-free slag to approximately $14 \mathrm{wt} \%$ in $5 \mathrm{wt} \% \mathrm{~K}_{2} \mathrm{O}$-containing slag.

\section{Discussion}

The behavior of a trace element in the experimental system under investigation can be described with the distribution coefficient. This thermodynamic parameter illustrates how an element [Me] is distributed between two phases in the system, in this case copper and slag. In sulfur-free systems, a typical equilibrium reaction is dissolution of the element [Me] into the slag phase as an oxide. Considering this oxidation reaction, the distribution coefficient can be defined according to Equation (1), and in logarithmic form according to Equation (2) [52]:

$$
\begin{gathered}
L^{(\text {copper/slag) }}[\mathrm{Me}]=[w t \% M e]_{\text {copper }} /(w t \% M e)_{\text {slag }}=[n T]\left(\gamma_{M O x}\right) / K(n T)\left[\gamma_{M}\right] p_{O 2}{ }^{x / 2} \\
\lg L^{(\text {copper/slag })}[\mathrm{Me}]=-x / 2 \lg p \mathrm{O}_{2}+\lg \mathrm{C}
\end{gathered}
$$

where [ ] and ( ) brackets refer to metal and slag phases, respectively, and $C$ includes the thermodynamic constants $K, n T$ and $\gamma$ (equilibrium constant of the aforementioned oxidation reaction, number of moles in $100 \mathrm{~g}$ of alloy and slag, and the activity coefficients of the investigated metal and its oxide form). Equation (2) proves extremely useful when plotting logarithm of the distribution coefficient as a function of logarithm of the oxygen pressure. Using this plot, the oxidation state of the element in the slag phase can be determined from the slope of a trend line fitted to the experimental result points.

This aforementioned distribution coefficient plot is drawn in Figure 7 for tin and in Figure 8 for antimony, with the results of some earlier studies for comparison. For tin, a value of approximately 60 was obtained in reducing experimental conditions (for slag without $\mathrm{K}_{2} \mathrm{O}$ ), indicating a 60 -fold concentration of tin in copper alloy phase compared to slag phase. As the conditions changed towards more oxidative, the concentration decreased in copper and increased in slag, and around $\mathrm{pO}_{2} 10^{-6} \mathrm{~atm}$, tin was distributed evenly between the two phases. Potassium oxide addition had clearly an increasing effect on the value of the distribution coefficient (more than $40 \%$ higher value at $10^{-10}$ atm $\mathrm{pO}_{2}$ ), indicating a better recovery of tin into the copper phase. The slopes of trend lines fitted to the experimental points were between -0.53 and -0.51 , which correspond to an oxidation degree of $\mathrm{Sn}^{2+}$, i.e., dissolution into the slags as $\mathrm{SnO}$. The obtained distribution coefficient values, as well as the oxide form are in fairly good agreement with previous publications [19-27] as far as relevant comparisons can be made. A comparison with the results obtained by Avarmaa et al. [27] with pure iron-silicate slag shows that saturating the slag with alumina does not have a very significant effect on the value of the distribution coefficient. Some researchers have suggested that with certain slags around $10^{-8} \mathrm{~atm}$ $\mathrm{pO}_{2}$, the slope of the trend line would change, corresponding to a change in the oxide form from $\mathrm{SnO}$ in reducing conditions to $\mathrm{SnO}_{2}$ in oxidizing process stages [21,24]. No evidence of such a change was found in this study with high-alumina iron silicate slags, with or without the addition of basic $\mathrm{K}_{2} \mathrm{O}$. 


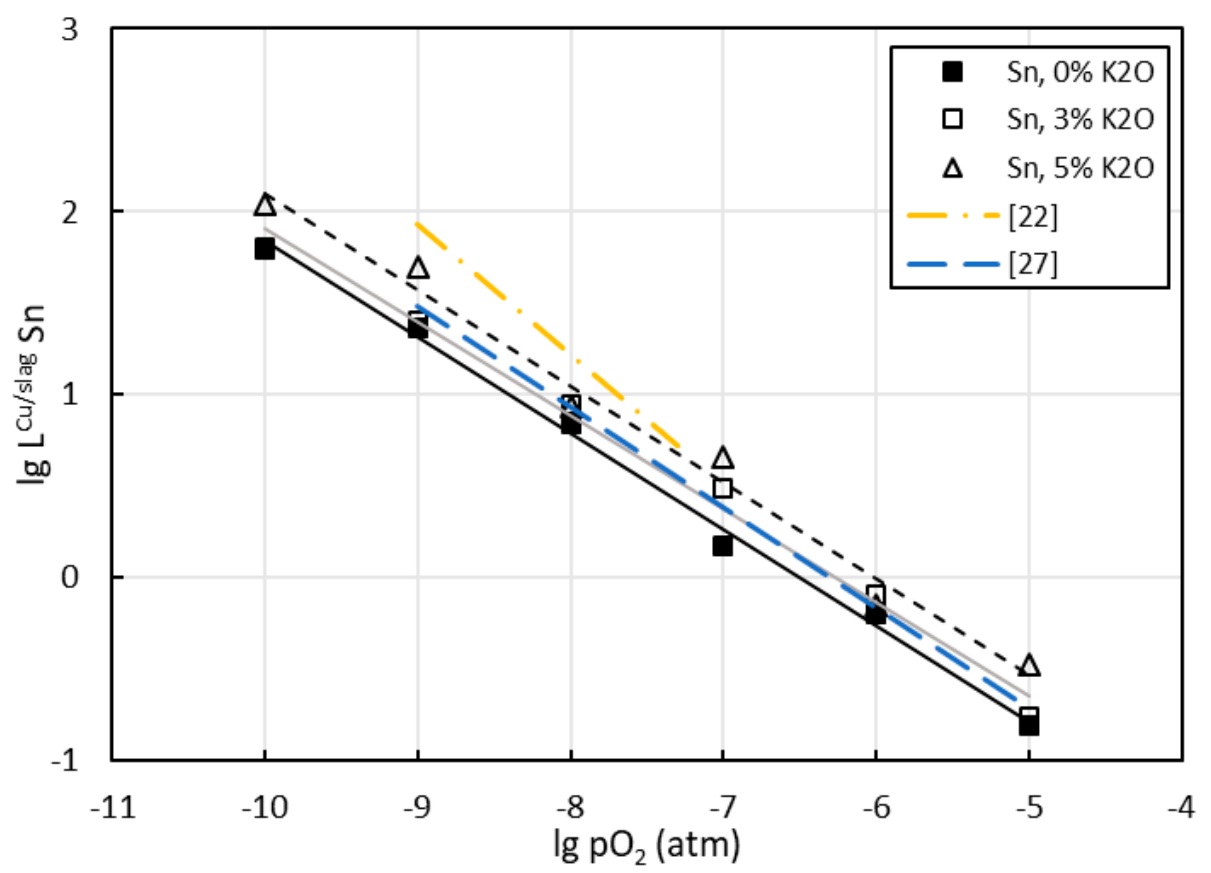

Figure 7. Distribution coefficient of tin between copper alloy and different slags as a function of oxygen partial pressure. For the concentrations in slags, LA-ICP-MS results were used below $10^{-8}$ atm $\mathrm{pO}_{2}$.

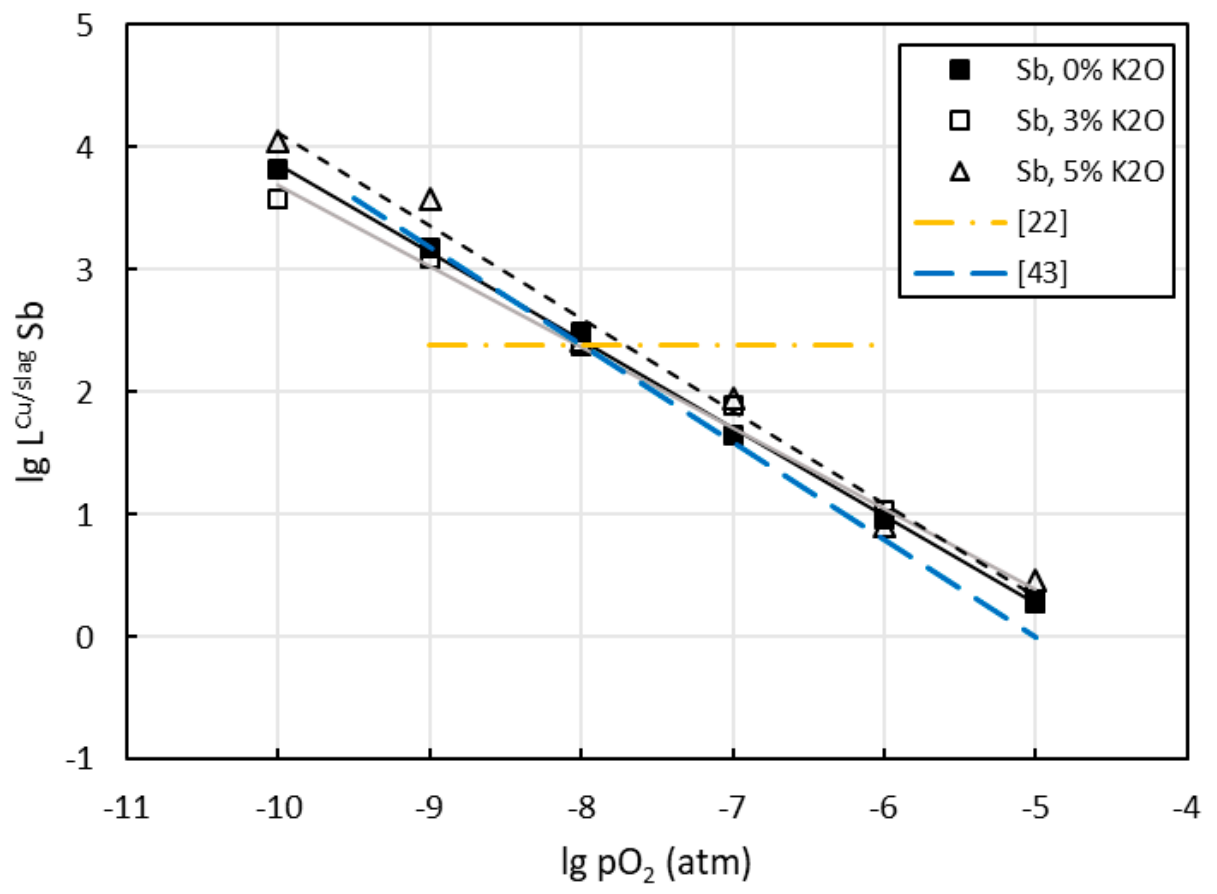

Figure 8. Distribution coefficient of antimony between copper alloy and different slags as a function of oxygen partial pressure. For the slags, LA-ICP-MS results were used below $10^{-6}$ atm $\mathrm{pO}_{2}$.

For antimony (Figure 8), the distribution coefficient in reducing conditions was approximately two orders of magnitude higher $\left(6500\right.$ with $\mathrm{K}_{2} \mathrm{O}$-free slag and 11,000 with $5 \mathrm{wt} \% \mathrm{~K}_{2} \mathrm{O}$-containing slag in $\mathrm{pO}_{2} 10^{-10} \mathrm{~atm}$ ) than for tin, and one order of magnitude higher in the oxidative side. The effect of $\mathrm{K}_{2} \mathrm{O}$ was notable for antimony as well. The slopes of the trend lines were between -0.76 and -0.66 , corresponding to an oxidation state of $\mathrm{Sb}^{3+}$ and dissolution into slags as $\mathrm{Sb}_{2} \mathrm{O}_{3}\left(\right.$ or $\mathrm{SbO}_{1.5}$ in monocationic form). The absolute values of distribution coefficients, as well as the dissolution form based on our results, correspond well with the observations of some earlier studies with calcium 
ferrite [21] and pure iron silicate slags [43]. The experimental distribution coefficient values from Hidayat et al. [43] overlap with our values obtained for slags without $\mathrm{K}_{2} \mathrm{O}$ in oxygen pressures below $10^{-7} \mathrm{~atm}$, and are slightly lower in higher oxygen pressures. It can therefore be concluded that the addition of approximately $18 \mathrm{wt} \%$ alumina into iron-silicate slag had only a minor effect of the distribution behavior of antimony.

Some researchers have also reported considerably less negative slopes, above $-0.38[39,40]$. The results of these studies may have been affected by the large sample size that slows the equilibration process, as explained by Hidayat et al. [43]. The independency of the distribution coefficient of antimony on the oxygen pressure, reported in $[22,38,41]$, is likely due to the inadequate detection limits of the analysis techniques used and the possibly incomplete phase separation prior to analyses.

Figure 9 shows a comparison regarding the concentrations of tin and antimony in slags, analyzed with EPMA and LA-ICP-MS techniques. As the figure indicates, LA-ICP-MS gave quite systematically lower results when the concentrations increased, which is due to the selection of a standard reference material. NIST 612 SRM [47] is perhaps the best commercially available choice for trace and ultra-trace element analysis from metallurgical slags with laser ablation, as it is a silicate (high concentration of silica, as is in our samples) and it has tens of different trace elements added. Therefore, it can be used as an external standard in the determination of concentrations of most trace elements of interest for metallurgists. One downside, however, is the possible interferences caused by the large number of trace elements, which can sometimes be corrected for by employing a correction factor [53].

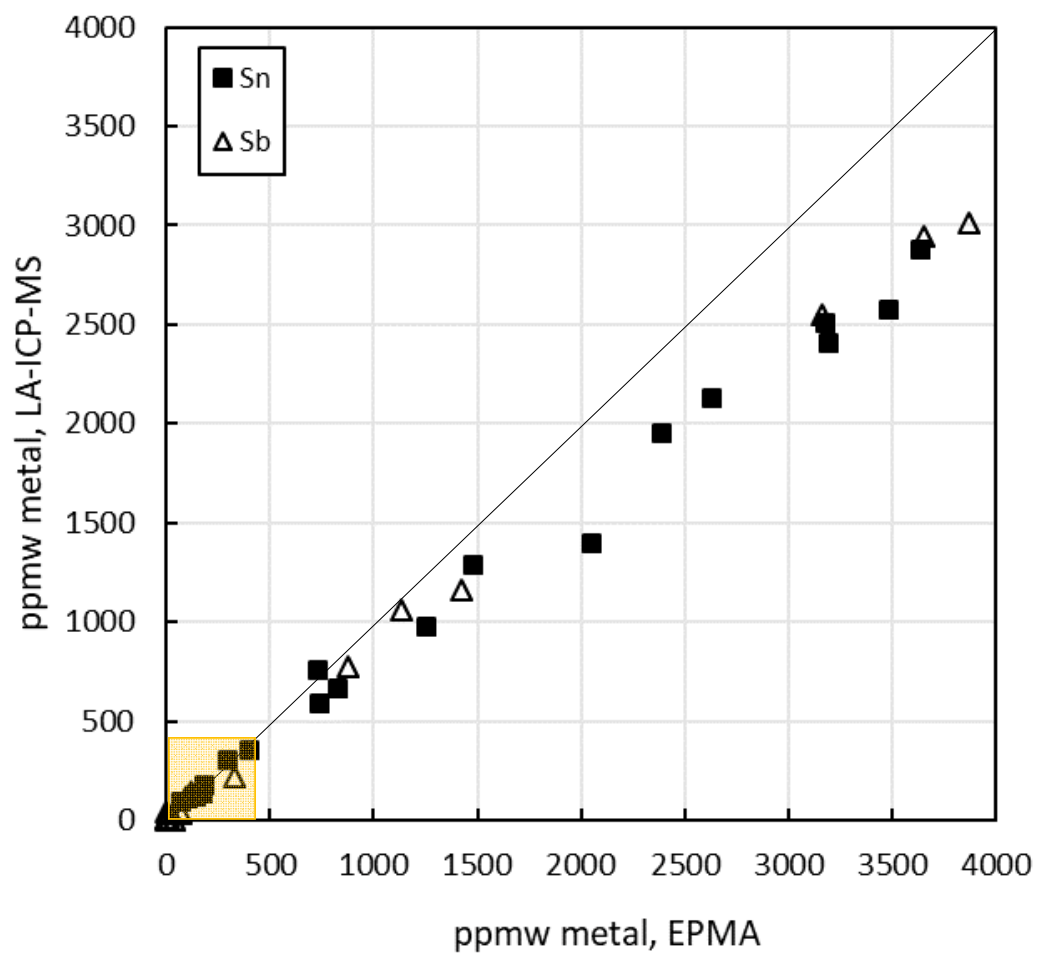

Figure 9. Concentrations of tin and antimony in slags, analyzed with EPMA and LA-ICP-MS techniques. For concentrations inside the orange square, LA-ICP-MS results were used. EPMA results were utilized for the higher concentrations.

The NIST 612 SRM contains approximately 39 ppmw tin and 35 ppmw antimony [47]. When the concentrations of these elements become high enough in the unknown samples, the extrapolation becomes so significant that it inevitably leads to reduced accuracy, as depicted in Figure 9. In this work, the purpose was to measure the trace element concentrations in the slag phase as reliably as possible throughout the entire concentration range. NIST 612 SRM is ideal for determining the low concentrations of tin and antimony in the slag in reducing conditions (numerical values in Table A3). 
For the more oxidizing conditions, i.e., higher trace element concentrations in slags, EPMA data was utilized. EPMA and LA-ICP-MS analysis results can be used as validation for each other in the concentration range suitable for the selected standard reference materials, however, in general, these techniques should not be considered as alternatives, but as complementary. LA-ICP-MS is perhaps the only technique for reliable analysis of ultra-trace concentrations $(<100 \mathrm{ppbw}$ : parts per billion by weight) directly from solid samples. With different commercially available or in-house standard reference materials, matched to the matrix of the unknown samples as well as possible, it also performs extremely well in trace or even minor element concentration range. In this work, the limits of quantification, i.e., the concentrations that can be reported reliably [23], of EPMA for tin and antimony were in the order of 400 ppmw, and therefore EPMA data was used above this concentration.

\section{Conclusions}

As the amount of electronic waste produced in the world is increasing rapidly, suitable and efficient recycling processes for this waste must be investigated and developed, as well as accurate experimental data obtained regarding the behavior of different elements in the processes. In this study, the behavior of tin and antimony was experimentally studied in secondary copper smelting conditions. The experimental system was comprised of gas-copper alloy-spinel saturated iron silicate slag with $0-5 \mathrm{wt} \% \mathrm{~K}_{2} \mathrm{O}$. The distribution coefficient between copper and slag increased for both metals as a function of decreasing oxygen partial pressure. Potassium oxide addition also increased the value of the copper-slag distribution coefficient, indicating a better recovery of the trace metals into the copper alloy phase, where they can be recovered in later process stages by vaporization into flue dusts or anode slime treatment for example. Therefore, it can be concluded that, when considering the recovery of tin and antimony, the presence of alkali metal oxides (for example $\mathrm{Na}_{2} \mathrm{O}$ or $\mathrm{K}_{2} \mathrm{O}$ ) in the industrial process should have a desirable effect. In oxidizing conditions, a significant part of tin was vaporized into the gas phase, highlighting the importance of trace metal recovery from the off-gases of different process stages.

If considerable amount of solid phases, such as different types of spinels, form during the industrial process, notable losses of copper and consequently trace elements into the slag may occur through mechanical entrainment of copper droplets. Therefore, as is well known in the industry, the formation of solid phases should be minimized; everything that is fed in should be tapped out. For reliable and accurate characterization of (ultra-)trace and minor element concentrations directly in each phase, EPMA together with LA-ICP-MS provides a powerful solution. These techniques should not be considered as alternatives, but as complementary, providing reliable data from ultra-trace concentrations all the way to major element composition.

Author Contributions: Conceptualization, L.K., P.T. and A.J.; methodology, L.K., K.A. and P.T.; software, L.K., H.O.; validation, L.K., K.A., H.O. and P.T.; formal analysis, L.K.; investigation, L.K., H.O.; resources, A.J.; writing—original draft preparation, L.K.; writing—review and editing, K.A., H.O., A.J. and P.T; visualization, L.K.; supervision, A.J.; funding acquisition, L.K. and A.J.

Funding: A research grant from the Finnish Steel and Metal Producers' Fund (L.K.) has enabled this work. The authors also acknowledge the financial support from Business Finland through CMEco project.

Acknowledgments: This study utilized the Academy of Finland's RawMatTERS Finland Infrastructure (RAMI) based at Aalto University. The work of Lassi Pakkanen from Geological Survey of Finland in conducting the EPMA analyses is greatly appreciated.

Conflicts of Interest: The authors declare no conflicts of interest. The funders had no role in the design of the study; in the collection, analyses, or interpretation of data; in the writing of the manuscript, or in the decision to publish the results. 


\section{Appendix A}

Table A1. List of experiments and experimental conditions. Temperature was kept constant at $1300{ }^{\circ} \mathrm{C}$.

\begin{tabular}{|c|c|c|c|c|c|}
\hline Sample ID & Slag & $\mathrm{pO}_{2}$ (atm) & $\mathrm{CO}(\mathrm{mL} / \mathrm{min})$ & $\mathrm{CO}_{2}(\mathrm{~mL} / \mathrm{min})$ & $\begin{array}{l}\text { Equilibration } \\
\text { Time (hours) }\end{array}$ \\
\hline $\mathrm{V}{ }^{1}$ & 3 wt $\% \mathrm{~K}_{2} \mathrm{O}$ & $10^{-6}$ & 4.1 & 295.9 & 8 \\
\hline $\mathrm{V} 1^{1}$ & 3 wt $\% \mathrm{~K}_{2} \mathrm{O}$ & $10^{-6}$ & 4.1 & 295.9 & 16 \\
\hline $\mathrm{V} 2^{1}$ & 3 wt $\% \mathrm{~K}_{2} \mathrm{O}$ & $10^{-6}$ & 4.1 & 295.9 & 24 \\
\hline V25 & no $\mathrm{K}_{2} \mathrm{O}$ & $10^{-5}$ & 1.3 & 298.7 & 16 \\
\hline V12, V13 & no $\mathrm{K}_{2} \mathrm{O}$ & $10^{-6}$ & 4.1 & 295.9 & 16 \\
\hline V11, V14 & no $\mathrm{K}_{2} \mathrm{O}$ & $10^{-7}$ & 12.6 & 287.4 & 16 \\
\hline V15, V18 & no $\mathrm{K}_{2} \mathrm{O}$ & $10^{-8}$ & 36.6 & 263.4 & 16 \\
\hline V16, V19 & no $\mathrm{K}_{2} \mathrm{O}$ & $10^{-9}$ & 91.5 & 208.5 & 16 \\
\hline V39 & no $\mathrm{K}_{2} \mathrm{O}$ & $10^{-10}$ & 174.4 & 125.6 & 16 \\
\hline V8 & 3 wt $\% \mathrm{~K}_{2} \mathrm{O}$ & $10^{-5}$ & 1.3 & 298.7 & 16 \\
\hline V7, V10 & 3 wt $\% \mathrm{~K}_{2} \mathrm{O}$ & $10^{-6}$ & 4.1 & 295.9 & 16 \\
\hline V6, V9 & 3 wt $\% \mathrm{~K}_{2} \mathrm{O}$ & $10^{-7}$ & 12.6 & 287.4 & 16 \\
\hline V21, V23 & 3 wt $\% \mathrm{~K}_{2} \mathrm{O}$ & $10^{-8}$ & 36.6 & 263.4 & 16 \\
\hline V20, V24 & 3 wt $\% \mathrm{~K}_{2} \mathrm{O}$ & $10^{-9}$ & 91.5 & 208.5 & 16 \\
\hline V22 & 3 wt $\% \mathrm{~K}_{2} \mathrm{O}$ & $10^{-10}$ & 174.4 & 125.6 & 16 \\
\hline V26 & $5 w t \% \mathrm{~K}_{2} \mathrm{O}$ & $10^{-5}$ & 1.3 & 298.7 & 16 \\
\hline V38 & 5 wt $\% \mathrm{~K}_{2} \mathrm{O}$ & $10^{-6}$ & 4.1 & 295.9 & 16 \\
\hline V28 & 5 wt $\% \mathrm{~K}_{2} \mathrm{O}$ & $10^{-7}$ & 12.6 & 287.4 & 16 \\
\hline V35 & 5 wt $\% \mathrm{~K}_{2} \mathrm{O}$ & $10^{-8}$ & 36.6 & 263.4 & 16 \\
\hline V30 & 5 wt $\% \mathrm{~K}_{2} \mathrm{O}$ & $10^{-9}$ & 91.5 & 208.5 & 16 \\
\hline V31 & 5 wt $\% \mathrm{~K}_{2} \mathrm{O}$ & $10^{-10}$ & 174.4 & 125.6 & 16 \\
\hline
\end{tabular}

Table A2. Concentrations of copper, tin and antimony in copper alloy phase. All results are from EPMA, in wt \%.

\begin{tabular}{cccc}
\hline \multicolumn{4}{c}{ Copper Alloy Phase } \\
\hline $0 \% \mathrm{~K}_{2} \mathrm{O}$ & \multicolumn{3}{c}{ wt \% } \\
\hline $\lg \mathbf{~ p O}_{2}$ (atm) & $\mathbf{C u}$ & $\mathrm{Sn}$ & $\mathrm{Sb}$ \\
\hline-5 & 96.66 & 0.06 & 0.70 \\
-6 & 96.69 & 0.20 & 1.05 \\
-7 & 97.14 & 0.30 & 1.00 \\
-8 & 95.31 & 0.57 & 1.15 \\
-9 & 95.43 & 0.81 & 1.11 \\
-10 & 94.92 & 0.83 & 0.97 \\
\hline $3 \% \mathrm{~K}_{2} \mathrm{O}$ & & $\mathrm{wt} \%$ & \\
\hline $\lg \mathrm{pO}_{2}$ (atm) & $\mathrm{Cu}$ & $\mathrm{Sn}$ & $\mathrm{Sb}$ \\
\hline-5 & 97.47 & 0.06 & 0.72 \\
-6 & 96.89 & 0.19 & 0.94 \\
-7 & 96.45 & 0.45 & 1.12 \\
-8 & 96.18 & 0.65 & 1.00 \\
-9 & 95.66 & 0.77 & 1.01 \\
-10 & 96.11 & 0.76 & 0.92 \\
\hline $5 \% \mathrm{~K}_{2} \mathrm{O}$ & & $\mathrm{wt} \%$ & \\
\hline $\lg \mathrm{pO}_{\mathbf{2}}$ (atm) & $\mathrm{Cu}$ & $\mathrm{Sn}$ & $\mathrm{Sb}$ \\
\hline-5 & 94.96 & 0.11 & 0.91 \\
-6 & 95.08 & 0.19 & 1.15 \\
-7 & 95.07 & 0.58 & 1.05 \\
-8 & 95.13 & 0.64 & 0.97 \\
-9 & 93.95 & 0.90 & 1.20 \\
-10 & 93.71 & 1.06 & 1.26 \\
\hline & & &
\end{tabular}


Table A3. Concentrations of iron, silicon, copper, aluminum, potassium, tin and antimony in slag phase. The concentrations of tin and antimony are shown in ppmw. LA-ICP-MS results have been used below $10^{-8}$ atm oxygen partial pressure for tin, and below $10^{-6}$ atm for antimony.

\begin{tabular}{|c|c|c|c|c|c|c|c|}
\hline \multicolumn{8}{|c|}{ Slag Phase } \\
\hline $0 \% \mathrm{~K}_{2} \mathrm{O}$ & \multicolumn{5}{|c|}{ wt $\%$} & \multicolumn{2}{|c|}{ ppmw } \\
\hline $\lg \mathrm{pO}_{2}(\mathrm{~atm})$ & $\mathrm{Fe}$ & $\mathrm{Si}$ & $\mathrm{Cu}$ & $\mathrm{Al}$ & K & Sn & $\mathrm{Sb}$ \\
\hline-5 & 23.54 & 13.07 & 20.75 & 9.42 & - & 3641.8 & 3652.8 \\
\hline-6 & 28.62 & 15.02 & 11.27 & 9.64 & - & 3195.2 & 1136.4 \\
\hline-7 & 32.75 & 15.48 & 6.37 & 9.75 & - & 2055.4 & 221.1 \\
\hline-8 & 36.10 & 15.42 & 3.02 & 9.75 & - & 823.3 & 37.0 \\
\hline-9 & 36.60 & 15.04 & 1.75 & 9.58 & - & 349.5 & 7.3 \\
\hline-10 & $>36.34$ & $>15.05$ & 1.07 & 9.94 & - & 134.5 & 1.5 \\
\hline $3 \% \mathrm{~K}_{2} \mathrm{O}$ & \multicolumn{5}{|c|}{ wt $\%$} & \multicolumn{2}{|c|}{ ppmw } \\
\hline $\lg \mathrm{pO}_{2}(\mathrm{~atm})$ & $\mathrm{Fe}$ & $\mathrm{Si}$ & $\mathrm{Cu}$ & Al & K & Sn & $\mathrm{Sb}$ \\
\hline-5 & 19.74 & 15.32 & 16.93 & 9.47 & 2.46 & 3487.3 & 3870.4 \\
\hline-6 & 22.93 & 17.50 & 8.89 & 9.56 & 2.76 & 2389.1 & 877.0 \\
\hline-7 & 28.57 & 17.39 & 4.49 & 9.26 & 2.77 & 1476.4 & 145.0 \\
\hline-8 & 32.12 & 16.99 & 2.48 & 9.35 & 2.61 & 731.0 & 41.4 \\
\hline-9 & 33.63 & 16.39 & 1.36 & 9.23 & 2.54 & 303.7 & 8.1 \\
\hline-10 & $>34.57$ & $>16.62$ & 0.93 & 9.48 & 2.47 & 117.6 & 2.5 \\
\hline $5 \% \mathrm{~K}_{2} \mathrm{O}$ & \multicolumn{5}{|c|}{ wt $\%$} & \multicolumn{2}{|c|}{ ppmw } \\
\hline $\lg \mathrm{pO}_{2}(\mathrm{~atm})$ & $\mathrm{Fe}$ & Si & $\mathrm{Cu}$ & Al & K & Sn & $\mathrm{Sb}$ \\
\hline-5 & 15.88 & 17.63 & 13.81 & 9.87 & 4.40 & 3181.9 & 3159.5 \\
\hline-6 & 17.28 & 19.48 & 9.03 & 9.31 & 5.05 & 2627.8 & 1423.4 \\
\hline-7 & 23.09 & 18.89 & 3.85 & 10.02 & 4.48 & 1255.9 & 118.4 \\
\hline-8 & 29.65 & 16.08 & 2.39 & 8.41 & 4.04 & 740.1 & 36.9 \\
\hline-9 & 29.10 & 17.17 & 1.07 & 9.81 & 3.97 & 179.5 & 3.1 \\
\hline-10 & 30.31 & 16.80 & 0.70 & 9.92 & 4.02 & 95.7 & 1.1 \\
\hline
\end{tabular}

Table A4. Concentrations of iron, silicon, copper, aluminum, potassium, tin and antimony in spinel phase. All values are shown in ppmw. The analyses were taken from spinels surrounded by slag whenever possible, i.e., when they formed (above $10^{-8}$ or $10^{-7} \mathrm{~atm}$ ). $<\mathrm{MDL}=$ below minimum detection limit of EPMA.

\begin{tabular}{|c|c|c|c|c|c|c|c|}
\hline \multicolumn{8}{|c|}{ Spinel Phase } \\
\hline $0 \% \mathrm{~K}_{2} \mathrm{O}$ & & & & $\mathrm{wt}^{\circ} \mathrm{O}$ & & & \\
\hline $\lg \mathrm{pO}_{2}$ (atm) & $\mathrm{Fe}$ & $\mathrm{Si}$ & $\mathrm{Cu}$ & $\mathrm{Al}$ & K & Sn & $\mathrm{Sb}$ \\
\hline-5 & 43.79 & 0.03 & 2.14 & 20.23 & - & 0.02 & $<\mathrm{MDL}$ \\
\hline-6 & 45.01 & 0.04 & 0.69 & 20.34 & - & 0.02 & 0.02 \\
\hline-7 & 41.67 & 0.05 & 0.30 & 22.93 & - & $<\mathrm{MDL}$ & 0.03 \\
\hline-8 & 38.99 & 0.05 & 0.12 & 25.87 & - & $<\mathrm{MDL}$ & $<\mathrm{MDL}$ \\
\hline-9 & 35.54 & 0.05 & 0.11 & 27.73 & - & $<\mathrm{MDL}$ & $<\mathrm{MDL}$ \\
\hline-10 & 32.71 & 0.03 & 0.08 & 29.61 & - & $<\mathrm{MDL}$ & $<\mathrm{MDL}$ \\
\hline $3 \% \mathrm{~K}_{2} \mathrm{O}$ & \multicolumn{7}{|c|}{ wt $\%$} \\
\hline $\lg \mathrm{pO}_{2}(\mathrm{~atm})$ & $\mathrm{Fe}$ & $\mathrm{Si}$ & $\mathrm{Cu}$ & Al & $\mathbf{K}$ & Sn & $\mathrm{Sb}$ \\
\hline-5 & 49.42 & 0.03 & 1.94 & 15.53 & $<\mathrm{MDL}$ & 0.05 & 0.03 \\
\hline-6 & 50.50 & 0.06 & 0.59 & 15.65 & $<\mathrm{MDL}$ & 0.03 & 0.02 \\
\hline-7 & 45.51 & 0.06 & 0.19 & 20.18 & $<\mathrm{MDL}$ & $<\mathrm{MDL}$ & 0.02 \\
\hline-8 & 40.76 & 0.09 & 0.17 & 25.00 & 0.01 & $<\mathrm{MDL}$ & $<\mathrm{MDL}$ \\
\hline-9 & 37.29 & 0.06 & 0.05 & 27.45 & $<\mathrm{MDL}$ & $<\mathrm{MDL}$ & $<\mathrm{MDL}$ \\
\hline-10 & 36.24 & 0.06 & 0.05 & 29.38 & $<\mathrm{MDL}$ & $<\mathrm{MDL}$ & $<\mathrm{MDL}$ \\
\hline $5 \% \mathrm{~K}_{2} \mathrm{O}$ & \multicolumn{7}{|c|}{ wt $\%$} \\
\hline $\lg \mathrm{pO}_{2}(\mathrm{~atm})$ & $\mathrm{Fe}$ & $\mathrm{Si}$ & $\mathrm{Cu}$ & Al & K & Sn & $\mathrm{Sb}$ \\
\hline-5 & 56.47 & 0.09 & 1.54 & 9.55 & $<\mathrm{MDL}$ & 0.12 & $<\mathrm{MDL}$ \\
\hline-6 & 60.10 & 0.06 & 0.70 & 7.98 & 0.01 & 0.10 & $<\mathrm{MDL}$ \\
\hline-7 & 45.07 & 0.06 & 0.27 & 20.06 & 0.03 & $<\mathrm{MDL}$ & $<\mathrm{MDL}$ \\
\hline-8 & 46.17 & 0.08 & 0.17 & 18.00 & 0.01 & $<\mathrm{MDL}$ & $<\mathrm{MDL}$ \\
\hline-9 & 35.48 & 0.14 & 0.05 & 27.61 & 0.07 & $<\mathrm{MDL}$ & $<\mathrm{MDL}$ \\
\hline-10 & 34.89 & 0.07 & 0.04 & 28.41 & 0.03 & $<\mathrm{MDL}$ & $<\mathrm{MDL}$ \\
\hline
\end{tabular}




\section{References}

1. Anindya, A.; Swinbourne, D.; Reuter, M.; Matusewicz, R. Tin distribution during smelting of WEEE with copper scrap. In Proceedings of the European Metallurgical Conference EMC2009, Innsbruck, Austria, 28 June-1 July 2009; GDMB Verlag GmbH: Clausthal-Zellerfeld, Germany, 2009; pp. 555-568.

2. Tsydenova, O.; Bengtsson, M. Chemical hazards associated with treatment of waste electrical and electronic equipment. Waste Manag. 2011, 31, 45-58. [CrossRef] [PubMed]

3. Hense, P.; Reh, K.; Franke, M.; Aigner, J.; Hornung, A.; Contin, A. Pyrolysis of Waste Electrical and Electronic Equipment (WEEE) for recovering metals and energy: Previous achievements and current approaches. Environ. Eng. Manag. J. 2015, 14, 1637-1647. [CrossRef]

4. Kojo, I.V.; Storch, H. Copper production with Outokumpu flash smelting: An update. In Proceedings of the Metals and Materials Volume 8: International Symposium on Sulfide Smelting 2006, San Diego, CA, USA, 27-31 August 2006; pp. 225-238.

5. Vanbellen, F.; Chintinne, M. Extreme makeover-UPMR's Hoboken plant. In Proceedings of the European Metallurgical Conference EMC2007, Dusseldorf, Germany, 11-14 June 2007; GDMB Verlag GmbH: Clausthal-Zellerfeld, Germany, 2007; Volume 1, pp. 371-380.

6. Woerz, H.; Wallner, J. Copper recycling plant at Brixlegg (Austria). In Proceedings of the Symposium on World Survey of Nonferrous Smelters, Phoenix, AZ, USA, 25-29 January 1988; Taylor, J.C., Traulsen, H.R., Eds.; Metallurgical Society of AIME: Warrendale, PA, USA, 1988; pp. 281-288.

7. Mackey, P.J.; Wraith, A.E. Development of copper quality: An historical perspective. Miner. Process. Extr. Metall. 2004, 113, 25-37. [CrossRef]

8. Cui, J.; Zhang, L. Metallurgical recovery of metals from electronic waste: A review. J. Hazard. Mater. 2008, 158, 228-256. [CrossRef] [PubMed]

9. Khaliq, A.; Rhamdhani, M.A.; Brooks, G.; Masood, S. Metal Extraction Processes for Electronic Waste and Existing Industrial Routes: A Review and Australian Perspective. Resources 2014, 3, 152-179. [CrossRef]

10. Havlik, T.; Orac, D.; Berwanger, M.; Maul, A. The effect of mechanical-physical pretreatment on hydrometallurgical extraction of copper and tin in residue from printed circuit boards from used consumer equipment. Miner. Eng. 2014, 65, 163-171. [CrossRef]

11. Havlik, T.; Orac, D.; Petranikova, M.; Miskufova, A.; Kukurugya, F.; Takacova, Z. Leaching of copper and tin from used printed circuit boards after thermal treatment. J. Hazard. Mater. 2010, 183, 866-873. [CrossRef]

12. Mecucci, A.; Scott, K. Leaching and electrochemical recovery of copper, lead and tin from scrap printed circuit boards. J. Chem. Technol. Biotechnol. 2002, 77, 449-457. [CrossRef]

13. Grimes, S.M.; Yasri, N.G.; Chaudhary, A.J. Recovery of critical metals from dilute leach solutions-Separation of indium from tin and lead. Inorg. Chim. Acta 2017, 461, 161-166. [CrossRef]

14. Takeda, Y.; Yazawa, A.; Chit, P.P.; Ujiie, H. Equilibria between Liquid Tin and $\mathrm{FeO}_{\mathrm{x}}-\mathrm{CaO}-\mathrm{SiO} 2 \mathrm{Slag}$. Mater. Trans. JIM 1990, 31, 793-801. [CrossRef]

15. Xu, X.; Hayes, P.C.; Jak, E. Phase equilibria in the "SnO"- $\mathrm{SiO}_{2}-$ "FeO" system in equilibrium with tin-iron alloy and the potential application for electronic scrap recycling. Int. J. Mater. Res. 2012, 103, 529-536. [CrossRef]

16. Yazawa, A. Thermodynamic Interpretation on Oxidic Dissolution of Metal in Slag. In Proceedings of the Australian Asian Pacific Course and Conference on Pyrometallurgy for Complex Materials and Wastes, Melbourne, Australia, 6-8 June 1994; Nilmani, M., Lehner, T., Rankin, W.J., Eds.; TMS: Warrendale, PA, USA, 1994; pp. 61-72.

17. Grimsey, E.J.; Dawson, P. High Temperature Electrochemical Measurement of Tin Oxide Activity in Slag. Proc. Australas. Inst. Min. Metall. 1983, 286, 15-21.

18. Rankin, W.J. The slag-metal equilibrium in tin smelting. Metall. Trans. B 1986, 17, 61-68. [CrossRef]

19. Anindya, A.; Swinbourne, D.R.; Reuter, M.A.; Matusewicz, R.W. Distribution of elements between copper and $\mathrm{FeO}_{\mathrm{x}}-\mathrm{CaO}-\mathrm{SiO}_{2}$ slags during pyrometallurgical processing of WEEE: Part 1-Tin. Miner. Process. Extr. Metall. 2013, 122, 165-173. [CrossRef]

20. Nagamori, M.; Mackey, P.J. Distribution equilibria of $\mathrm{Sn}$, Se and Te between $\mathrm{FeO}-\mathrm{Fe}_{2} \mathrm{O}_{3}-\mathrm{SiO}_{2}-\mathrm{AI}_{2} \mathrm{O}_{3}-\mathrm{CuO}_{0.5}$ slag and metallic copper. Metall. Trans. B 1977, 8, 39-46. [CrossRef]

21. Takeda, Y.; Ishiwata, S.; Yazawa, A. Distribution equilibria of minor elements between liquid copper and calcium ferrite slag. Trans. Jpn. Inst. Met. 1983, 24, 518-528. [CrossRef] 
22. See, J.B.; Rankin, W.J. Copper Losses and the Distribution of Impurities in the Systems $\mathrm{FeO}-\mathrm{Fe}_{2} \mathrm{O}_{3}-\mathrm{SiO}_{2}-\mathrm{Al}_{2} \mathrm{O}_{3}-\mathrm{Cu}$ and $\mathrm{FeO}-\mathrm{Fe}_{2} \mathrm{O}_{3}-\mathrm{SiO}_{2}-\mathrm{Al}_{2} \mathrm{O}_{3}-\mathrm{CaO}-\mathrm{Cu}$ at $1300{ }^{\circ} \mathrm{C}$; National Institute for Metallurgy, process development division: Randburg, South Africa, 1981; 22p.

23. Van den Bulck, A.; Turner, S.; Guo, M.; Malfliet, A.; Blanpain, B. The Distribution of Sn between $\mathrm{CaO}-\mathrm{CuO}_{\mathrm{x}}-\mathrm{FeO}_{\mathrm{y}}-\mathrm{SiO}_{2}$ Slag and Copper Metal at $1300{ }^{\circ} \mathrm{C}$. In Proceedings of the Extraction 2018, Ottawa, ON, Canada, 26-29 August 2018; Springer: Cham, Switzerland, 2018; pp. 1083-1092.

24. Gortais, J.; Hodaj, F.; Allibert, M.; Welter, J.M. Equilibrium distribution of Fe, Ni, Sb, and Sn between liquid $\mathrm{Cu}$ and a CaO-rich slag. Metall. Mater. Trans. B 1994, 25, 645-651. [CrossRef]

25. Avarmaa, K.; Yliaho, S.; Taskinen, P. Recoveries of rare elements Ga, Ge, In and Sn from waste electric and electronic equipment through secondary copper smelting. Waste Manag. 2018, 71, 400-410. [CrossRef]

26. Avarmaa, K.; Taskinen, P. The Influence of Aluminum on Indium and Tin Behaviour during Secondary Copper Smelting. In Proceedings of the Extraction 2018, Ottawa, ON, Canada, 26-29 August 2018; Springer: Cham, Switzerland, 2018; pp. 1061-1071.

27. Avarmaa, K.; Klemettinen, L.; O’Brien, H.; Taskinen, P. The behavior of tin in black copper smelting conditions with different iron-silicate based slags. In Proceedings of the EMC2019, Dusseldorf, Germany, 23-26 June 2019.

28. Dupont, D.; Arnout, S.; Jones, P.T.; Binnemans, K. Antimony Recovery from End-of-Life Products and Industrial Process Residues: A Critical Review. J. Sustain. Metall. 2016, 2, 79-103. [CrossRef]

29. Tostar, S.; Stenvall, E.; Boldizar, A.; Foreman, M. Antimony leaching in plastics from waste electrical and electronic equipment (WEEE) with various acids and gamma irradiation. Waste Manag. 2013, 33, 1478-1482. [CrossRef]

30. Shotyk, W.; Krachler, M.; Chen, B. Contamination of Canadian and European bottled waters with antimony from PET containers. J. Environ. Monit. 2006, 8, 288-292. [CrossRef] [PubMed]

31. Cornelis, G.; Van Gerven, T.; Vandecasteele, C. Antimony leaching from uncarbonated and carbonated MSWI bottom ash. J. Hazard. Mater. 2006, 137, 1284-1292. [CrossRef] [PubMed]

32. McNutt, M.K.; Salazar, K. Mineral Commodity Summaries 2012; U.S. Geological Survey: Reston, VA, USA, 2012; pp. 18-19. ISBN 978-1-4113-3349-9.

33. European Commission. Report on Critical Raw Materials for the EU: Report of the Ad hoc Working Group on Defining Critical Raw Materials; European Commission, DG Enterprise \& Industry: Brussels, Belgium, 2014.

34. Cornelis, G.; Van Gerven, T.; Vandecasteele, C. Antimony leaching from MSWI bottom ash: Modelling of the effect of $\mathrm{pH}$ and carbonation. Waste Manag. 2012, 32, 278-286. [CrossRef] [PubMed]

35. Zhang, B.; Li, Q.; Shen, W.; Min, X. Recovery of bismuth and antimony metals from pressure-leaching slag. Rare Met. 2012, 31, 102-106. [CrossRef]

36. Boerrigter, H. Implementation of thermal processes for feedstock recycling of bromine and antimony, with energy recovery, from plastics waste of electrical and electronic equipment (WEEE). In Phase 1: Literature Survey/Status Update, Evaluation, and Ranking of Combustion, Gasification, and Pyrolysis Based Technologies; Energy research Centre of the Netherlands (ECN): Petten, The Netherlands, 2000.

37. Boerrigter, H. Implementation of thermal processes for feedstock recycling of bromine, with energy recovery, from plastics waste of electrical and electronic equipment (WEEE). In Phase 2: Production of Bromine Salt in Staged-Gasification to Determine Technical Feasibility of Bromine Recovery; Energy research Centre of the Netherlands (ECN): Petten, The Netherlands, 2001.

38. Nagamori, M.; Mackey, P.J.; Tarassoff, P. Copper Solubility in $\mathrm{FeO}-\mathrm{Fe}_{2} \mathrm{O}_{3}-\mathrm{SiO}_{2}-\mathrm{Al}_{2} \mathrm{O}_{3} \mathrm{Slag}$ and Distribution Equilibria of Pb, Bi, Sb and As Between Slag and Metallic Copper. Metall. Trans. B 1975, 6B, $295-301$. [CrossRef]

39. Goto, S.; Ogawa, O.; Inoue, Y.; Ohara, H. On the Equilibria Between Cu-Sb Alloys and Silica-Saturated Iron Silicate Slags: Behavior of Impurities in Copper Smelting (1st. Report). J. Min. Inst. Jpn. 1979, 95, $205-211$. [CrossRef]

40. Jimbo, I.; Goto, S.; Ogawa, O. Equilibria between silica-saturated iron silicate slags and molten $\mathrm{Cu}-\mathrm{As}, \mathrm{Cu}-\mathrm{Sb}$, and Cu-Bi Alloys. Metall. Trans. B 1984, 15, 535-541. [CrossRef]

41. Kim, H.G.; Sohn, H.Y. Effects of $\mathrm{CaO}, \mathrm{Al}_{2} \mathrm{O}_{3}$, and $\mathrm{MgO}$ Additions on the Copper Solubility, Ferric/Ferrous Ratio, and Minor-Element Behavior of Iron-Silicate Slags. Metall. Mater. Trans. B 1998, 29B, 583-590. [CrossRef] 
42. Kaur, R.R.; Swinbourne, D.R.; Nexhip, C. Nickel, lead and antimony distributions between ferrous calcium silicate slag and copper at $1300^{\circ} \mathrm{C}$. Miner. Process. Extr. Metall. 2009, 118, 65-72. [CrossRef]

43. Hidayat, T.; Chen, J.; Hayes, P.C.; Jak, E. Distributions of Ag, Bi, and $\mathrm{Sb}$ as Minor Elements between Iron-Silicate Slag and Copper in Equilibrium with Tridymite in the $\mathrm{Cu}-\mathrm{Fe}-\mathrm{O}-\mathrm{Si}$ System at $\mathrm{T}=1250{ }^{\circ} \mathrm{C}$ and $1300{ }^{\circ} \mathrm{C}(1523 \mathrm{~K}$ and $1573 \mathrm{~K})$. Metall. Mater. Trans. B 2018. [CrossRef]

44. Yazawa, A. Distribution of various elements between copper, matte and slag. Erzmetall 1980, 33, 377-382.

45. Klemettinen, L.; Avarmaa, K.; Taskinen, P.; Jokilaakso, A. Behavior of nickel as a trace element and time-dependent formation of spinels in WEEE smelting. In Proceedings of the Extraction 2018, Ottawa, ON, Canada, 26-29 August 2018; Springer: Cham, Switzerland, 2018; pp. 1073-1082.

46. Pouchou, J.L.; Pichoir, F. Basic expression of "PAP" computation for quantitative EPMA. In Proceedings of the 11th International Congress on X-ray Optics and Microanalysis ICXOM, London, UK, 4-8 August 1986; Brown, J.D., Packwood, R.H., Eds.; Graphic Services, University of Western Ontario: London, ON, Canada, 1986; pp. 249-256.

47. Jochum, K.P.; Weis, U.; Stoll, B.; Kuzmin, D.; Yang, Q.; Raczek, I.; Jacob, D.E.; Stracke, A.; Birbaum, K.; Frick, D.A.; et al. Determination of Reference Values for NIST SRM 610-617 Glasses Following ISO Guidelines. Geostand. Geoanal. Res. 2011, 35, 397-429. [CrossRef]

48. Griffin, W.L.; Powell, W.J.; Pearson, N.J.; O’Reilly, S.Y. GLITTER: Data Reduction Software for Laser Ablation ICP-MS. In Laser Ablation-ICP-MS in the Earth Sciences: Current Practices and Outstanding Issues; Sylvester, P.J., Ed.; Short Course Series \#40; Mineralogical Association of Canada: Quebec, QC, Canada, 2008; pp. 308-311, ISBN 9-0-921294-49-8.

49. De Wilde, E.; Bellemans, I.; Kampforts, M.; Guo, M.; Blanpain, B.; Moelans, N.; Verbeken, K. Investigation of High Temperature Slag/Copper/Spinel Interactions. Metall. Mater. Trans. B 2016, 47, 1-14. [CrossRef]

50. De Wilde, E.; Bellemans, I.; Kampforts, M.; Guo, M.; Vanmeensel, K.; Blanpain, B.; Moelans, N.; Verbeken, K. Study of the Effect of Spinel Composition on Metallic Copper Losses in Slags. J. Sustain. Metall. 2017, 3, 416-427. [CrossRef]

51. Rämä, M.; Nurmi, S.; Jokilaakso, A.; Klemettinen, L.; Taskinen, P.; Salminen, J. Thermal Processing of Jarosite Leach Residue for a Safe Disposable Slag and Valuable Metals Recovery. Metals 2018, 8, 744. [CrossRef]

52. Yazawa, A.; Nakazawa, S.; Takeda, Y. Distribution behavior of various elements in copper smelting systems. In Proceedings of the International Sulfide Smelting Symposium: Advances in Sulfide Smelting, San Francisco, CA, USA, 6-9 November 1983; Volume 1, pp. 99-117.

53. Sylvester, P.J. A Practical Guide to Platinum-group Element Analysis of Sulphides by Laser-ablation ICPMS. In Laser-Ablation in the Earth Sciences: Principles and Application; Sylvester, P.J., Ed.; Short Course Series \#40; Mineralogical Association of Canada: Quebec, QC, Canada, 2001; pp. 203-213, ISBN 978-092-12942-9-0. 